\title{
Empirical Study on the Correlation between Stock Incentive and Corporate Performance of Energy Listed Companies
}

\author{
Yongchen $\mathrm{LI}^{1, \mathrm{a}}$, Fang $\mathrm{LI}^{1, \mathrm{~b}}$ \\ ${ }^{1}$ School of Economics and Management, North China Electric Power University, Baoding 071000 \\ China \\ a1510142150@qq.com, bWorkmbox_beryl@126.com
}

Keywords: Energy industry; stock incentive; corporate performance; least squares

\begin{abstract}
To explore the effects and improvement approaches of executive incentive in Chinese listed company, data from 2009 to 2013 of A-share listed companies in energy industry has been chosen to analyze correlation between executive ownership and corporate performance and correlation between executive compensation and corporate performance respectively based on least squares in this paper. And the results show that the proportion of executives ownership of these companies are generally low, and there is no correlation with corporate performance, which means that executive equity incentive has little effect on corporate performance. While there are great differences in the level of executive compensation that significantly positive correlation with corporate performance. So, the effect of salary incentive should be paid attention to emphatically when designing stock incentive mechanism for listed companies in energy industry, and a reasonable proportion of executive ownership should be explored with the reform and development situation of companies considered.
\end{abstract}

\section{Introduction}

According to the principal-agent theory, due to the asymmetry of information, operators are likely to harm owners' interests in the case of them without knowing, when there is a conflict in the interests between owners and operators, and this requires effective Stock incentive mechanism to guide and restrain such acts of executive, which is an important and difficult point of deepening the reform of the energy sector in China. This paper is trying to explore the correlation respectively between Stock incentives of managerial ownership and Executive compensation and corporate performance by taking listed companies in energy industry of China as the object of research and analyzing data of them from 2009 to 2013. And proposal for the establishment of Stock incentive mechanism are put forward on the basis of empirical analysis.

Chinese scholars come to different conclusions in study about correlation between managerial ownership and corporate performance. Some scholars like Ming $\mathrm{Hu}^{[1]}$, Bin $\mathrm{Gu}$ and Liye Zhou ${ }^{[2]}$ believe that executive equity incentive and corporate performance is not associated because of a late start of practice and a small number of executive holdings in Chinese enterprises. But with the further development of executive shareholding system and the increase in the number of holdings, more and more scholars have found a correlation between them. For examples, Liuchi Wang and Mei Wang ${ }^{[3]}$ found a no significant correlation between managerial ownership and corporate performance, the conclusion that there is a positive U-shaped relationship between ownership concentration and corporate performance have been given by study of Zhenhua Li and Qiongshi Feng ${ }^{[4]}$, while Yuting Wang and Pengcheng Du ${ }^{[5]}$ stand by a cubic relationship between equity incentive and corporate performance.

Although it remains disputed also in domestic academia on correlation between Executive compensation and corporate performance, studies of a vast majority of scholars have shown that Executive compensation and corporate performance are positively correlated with different degree of correlation. ${ }^{[6-9]}$

Overall, domestic studies on Stock incentive and corporate performance have covered listed companies of different areas, types and properties, but less for a specific industry. Meanwhile, existing research findings are significant different about this issue for some reasons, such as the diversity of samples, statistical methods and metrics for variables. 


\section{Research Design}

\subsection{Hypotheses.}

Chinese listed companies in energy industry are state-owned holding company, and data from eighty of them show a low proportion of executive holdings on the whole. The companies with no executive holdings take up 56.8 percent, and there are approximately $40.9 \%$ of the companies of which proportion of executive holdings ranging from 0 to 0.5 percent. This article made the following assumptions base on existing research findings.

H1: Managerial ownership and corporate performance is irrelevant in listed companies of energy industry;

H2: Executive compensation and corporate performance is significantly positive correlation in listed companies of energy industry.

\subsection{Study Samples and Variables.}

Three hundred eighty-four effect samples are used for empirical research after excluding some abnormal study samples, and all raw data is from the GTA database (CSMAR). Variables are set as shown in Table 1.

Table 1 List of Variables

\begin{tabular}{|c|c|c|c|}
\hline Variable categories & Symbol & Variables & Calculation \\
\hline Explained variable & $R O E$ & Rate of Return on Common & Directly obtained \\
\hline \multirow{2}{*}{ Explanatory variables } & ESH & Executive Ownership & $\begin{array}{l}\text { Number of Executives shares / Total } \\
\text { shares }\end{array}$ \\
\hline & $E P$ & Executive compensation & $\begin{array}{l}\text { Ln(total Salary (million) of the top three } \\
\text { executives) }\end{array}$ \\
\hline \multirow{4}{*}{ controlled variables } & SIZE & Company Size & Ln(total assets) \\
\hline & $D U A L$ & Two Level Settings & $\begin{array}{l}\text { Taking } 1 \text { if chairman and general } \\
\text { manager positions are held by one person } \\
\text { or } 2 \text { if not }\end{array}$ \\
\hline & LEV & Financial Leverage & Debt to Assets Ratio \\
\hline & GROW & Ability to Grow & Net Profit Growth Rate \\
\hline
\end{tabular}

\subsection{Research Method.}

Statistical Product and Service Solutions software will be used in this paper for descriptive statistics and correlation analysis of data, and empirical analysis about correlation between Stock incentive and corporate performance based on Multiple Linear Regression Model. And Specific model is as follow:

$$
R O E=\alpha_{0}+\alpha_{1} \times E H S+\alpha_{2} \times E P+\sum_{3}^{6} \alpha_{\mathrm{i}} \times \text { Determinants }+\varepsilon_{1}
$$

Determinants in formula (1) represents set of control variables affecting corporate performance. Backward Delete method will be used in the following study to filter variables in the model.

\subsection{Statistical Product and Service Solutions.}

The result of descriptive statistics of all variables presented in Table 2 mainly shows two statuses about explanatory variables. First, there is a low overall level of proportion of executives holding with a maximum of 64 percent, average value of 1.5 percent and Median of zero. Second, a large gap exists between the level of Executive compensation with a maximum of 6.32 and minimum of 1.49 .

Table 2 Descriptive Statistics of Variables

\begin{tabular}{cccccccc}
\hline Var. & $\mathrm{N}$ & Max. & Min. & Med. & Ave. & SEM & STD \\
\hline ROE & 384 & -7.44 & .57 & .0795 & .0418 & .0216 & .42348 \\
$E S H$ & 384 & .00 & .64 & .0000 & .0149 & .0034 & .06739 \\
EP & 384 & 1.49 & 6.32 & 4.7560 & 4.6799 & .0313 & .61295 \\
SIZE & 384 & 9.48 & 17.19 & 13.3215 & 13.4190 & .0751 & 1.47069 \\
DUAL & 379 & 1 & 2 & 2 & 1.9200 & .0140 & .2780 \\
LEV & 384 & .01 & 1.26 & .6039 & .5948 & .0095 & .18560 \\
GROW & 384 & -282.14 & 13.85 & .0202 & -1.6931 & .8346 & 16.35507 \\
\hline
\end{tabular}


The Pearson Correlation coefficients between any two of all variables are presented in Table 3. On one hand, company performance is positively correlated with incentive levels of Executive compensation at significance level of 1 percent, while not correlated significantly with the proportion of executives holding, and significantly correlated with variables of SIZE, DUAL, LEV and GROW. On the other hand, no serious collinearity among explanatory variables and control variables since the correlation coefficients between all variables are lower than 0.65.

Table 3 Pearson Correlation Coefficient Matrix of Variables

\begin{tabular}{cccccccc}
\hline Var. & $R O E$ & $E S H$ & $E P$ & $S I Z E$ & $D U A L$ & $L E V$ & $G R O W$ \\
\hline$R O E$ & 1 & & & & & & \\
$E S H$ & -.076 & 1 & & & & & \\
$E P$ & $.248^{* *}$ & $.102^{*}$ & 1 & & & & \\
SIZE & $.203^{* *}$ & -.033 & $.628^{* *}$ & 1 & & & \\
DUAL & $-.104^{*}$ & .057 & .074 & $.217^{* *}$ & 1 & & \\
LEV & $-.201^{* *}$ & .039 & .067 & $.354^{* *}$ & $.118^{*}$ & 1 & \\
GROW & $.349^{* *}$ & -.068 & $.144^{* *}$ & $.194^{* *}$ & -.031 & -.096 & 1 \\
\hline
\end{tabular}

\section{Empirical Analysis}

\subsection{Regression Model.}

This paper use ordinary least squares to analyze the multivariate linear regression model. To improve the estimation accuracy of model, delete backwards regression method is used to define optimal set of independent variables with F probability entry criteria set as 0.05 and delete standard as 0.1 . The final model is as follow:

$$
R O E=\beta_{0}+\beta_{1} \times E P+\beta_{2} \times S I Z E+\beta_{3} \times D U A L+\beta_{4} \times L E V+\beta_{5} \times G R O W+\varepsilon_{2}
$$

The results of regression are shown in Table 4, and analysis found a number of phenomena.

Firstly, all variance inflation factors calculated are less than 3 and tolerance values are higher than 0.5, which explain further that no serious multicollinearity exists between independent variables. Furthermore, F test value signified on level of 5 percent shows that the overall regression coefficient is significant and Adjusted R-squared of 0.706 indicates a goodness of fit.

Secondly, on the one hand, the significant test result of correlation between proportion of managerial ownership and corporate performance is much greater than 0.05 , which shows that there is no significant correlation between them in domestic listed companies in energy industry; on the other hand, correlation analysis also present correlation coefficient of -0.076 for them, absolute value of which is much smaller than value of 0.3 . Therefore, it can be judged that there is no linear correlation between them, which verifies the hypothesis $\mathrm{H} 1$.

Thirdly, the significant test result of correlation between levels of Executive compensation and corporate performance is far less than value of 0.05 , which shows a significant positive correlation between them with coefficient of 0.122 and verifies the hypothesis $\mathrm{H} 2$.

At last, the significant test results of SIZE, DUAL, LEV, GROW and constant term are all less than value of 0.05 , which means that they all have significant impact on corporate performance.

Table 4 OLS results of Stock incentive and corporate performance

\begin{tabular}{cccccc}
\hline Var. & $\mathrm{B}$ & $\mathrm{t}$ & Sig. & Tol. & VIF \\
\hline$C$ & .799 & 2.444 & .015 & & \\
ESH & -.057 & -.971 & .332 & .960 & 1.041 \\
$E P$ & .122 & 2.027 & .043 & .569 & 1.756 \\
SIZE & .180 & 2.680 & .008 & .462 & 2.163 \\
DUAL & -.422 & -2.495 & .013 & .941 & 1.063 \\
LEV & -.227 & -4.432 & .000 & .802 & 1.248 \\
GROW & .266 & 5.600 & .000 & .925 & 1.081
\end{tabular}

Adjusted R-Square $=.706 \quad$ Durbin-Watson=1.679 $\mathrm{F}=20.621(.000)$

The correlation model of excitation level for executives and corporate performance in domestic listed companies in energy industry can inferred as follow: 
$R O E=0.799+0.122 \times E P+0.18 \times S I Z E-0.422 \times D U A L-0.227 \times L E V+0.266 \times G R O W$

\subsection{Residuals Test.}

Since standardized residuals distribution of $\varepsilon_{2}$ infinitely close to the standard normal distribution, and the significance of single sample K-S test result is value of 0.103 , the residual meet the hypothesizes of normality and unbiasedness. Additionally, residuals scatterplot shows relative random distribution of residuals with no outliers and D-W test statistic is value close to value of 2 of 1.679 also, which show that residuals satisfy the assumption of homogeneity of variance and are well in independence.

\subsection{Robustness Test.}

In order to conduct robustness tests for model (2) based on consideration of heteroscedasticity that may be present in the selected data, this paper uses median regression to analyze model (2), and the results broadly consistent with the OLS regression results is shown in Table 5.

Table 5 Median Regression Results of Stock Incentive and Corporate Performance

\begin{tabular}{ccccc}
\hline Var. & Coefficient & Std. & t-Statistic & Prob. \\
\hline$C$ & 0.634 & 0.059 & 3.942 & 0.021 \\
$E S H$ & -0.231 & 0.058 & -0.124 & 0.522 \\
$E P$ & 0.149 & 0.074 & 0.641 & 0.038 \\
SIZE & 0.223 & 0.210 & 3.272 & 0.006 \\
DUAL & -0.387 & 0.063 & -2.369 & 0.009 \\
LEV & -0.229 & 0.078 & -5.448 & 0.001 \\
GROW & 0.254 & 0.498 & 2.946 & 0.000 \\
Adjusted-R-Square $=0.172$ & Quasi-LR statistic $=109.802(0.000)$ & & \\
\hline
\end{tabular}

\section{Conclusion}

There are two discoveries in this paper. First, Equity incentive has little impact on company performance since that level of managerial ownership is generally low and not related to corporate performance. Second, executive compensation and corporate performance show significant positive correlation. Therefore, the effect of salary incentive should be paid attention to emphatically when designing stock incentive mechanism for listed companies in energy industry, and incentive executives' effort to devote their special value for the promotion of corporate performance by setting a reasonable salary level after comparing with executive compensation and internal staff salaries in the same industry. In above process, the reform and development situation of companies should be taken into account also to explore a reasonable proportion of managerial ownership further.

It should also be studied deeply that interaction between executive ownership and Executive compensation, their impact on corporate performance and reasonable proportion of executive ownership in future studies.

\section{References}

[1]. Ming Hu. Study on Independence of the Board of Directors of Chinese Listed Companies [J]. Jiaxing University, 2003, (02):72-75. (In Chinese)

[2]. Bin Gu, Liye Zhou. Study on the Effect of the Implementation Stock Incentives by Chinese Listed Companies [J]. Accounting Research, 2007 (02): 79-84. (In Chinese)

[3]. Liuchi Wang, Mei Wang. Empirical Study of Equity Incentive and Enterprise Performance of Chinese Listed Companies [J]. Journal of Nanjing University of Finance and Economics, 2014, (01): 41-46. (In Chinese)

[4]. Zhenhua Li, Qiongshi Feng, Dapang Lin. CFO stock incentive and Corporate Performance: An Empirical Study of Chinese Listed Companies [J]. Enterprise Economy, 2012 (05): 176-179. (In Chinese) 
[5]. Yuting Wang, Pengcheng Du, Dan Yang. Empirical Study on Stock Incentive and Performance of High-tech Enterprise - Based on panel data of Listed Information Technology Enterprises in China [J]. Science \& Technology and Economy, 2012, (03): 46-50. (In Chinese)

[6]. Jinlin Zhang, Bo Zhao. Empirical Study on Correlation between Executive compensation and Corporate Performance of Chinese Listed Company [J]. Inquiry into Economic Issues, 2010, (06): 81-87. (In Chinese)

[7]. Changgeng Liu, Wei Wang, Ming Xu. The Performance, Characteristics of Capital Market and Executive Compensation Incentive of Listed Companies in China- Taking Listed Companies in Hunan as An Example [J]. Economic Survey, 2014, 31 (3): 90-96. (In Chinese)

[8]. Xianming Wen, Qiulan Tie, Yinqi Huang. An Empirical Study on the Relationship between Executive Compensation and Corporate Performance - Take Small Plates Listed Companies as an Example [J]. The Theory and Practice of Finance and Economics, 2015, (02): 71-76. (In Chinese)

[9]. Aijun Zeng. Study of the relationship between Management Compensation and Listed Companies Performance [J]. The Theory and Practice of Finance and Economics, 2013, (04): 64-67. (In Chinese) 